\title{
Protected areas host important remnants of marine turtle nesting stocks in the Dominican Republic
}

\author{
Ohiana Revuelta, Yolanda M. León, Pablo Feliz, Brendan J. Godley \\ JuAn A. RAgA and Jesús Tomás
}

\begin{abstract}
Nesting by marine turtles in the Caribbean has declined considerably, mainly because of human exploitation, but there has previously been no monitoring in the Dominican Republic. We present the first detailed assessment of the status of marine turtle nesting in the country, based on surveys during 2006-2010. Nesting populations of hawksbill Eretmochelys imbricata and leatherback turtle Dermochelys coriacea are of regional importance and the green turtle Chelonia mydas is still present, although nesting in low numbers. The two main nesting sites are within protected areas: the Jaragua National Park in the south-west, important for leatherback turtles (mean of 126 nests per season), and Del Este National Park on Saona Island in the south-east, principally for hawksbill turtles (mean of 100 nests per season). Comparison with historical data suggests all rookeries are profoundly reduced in size. Although the main nesting beaches are within protected areas, illegal egg-take and meat consumption continues there, and also elsewhere in the country.
\end{abstract}

Keywords Caribbean, Chelonia mydas, Dermochelys coriacea, Dominican Republic, Eretmochelys imbricata, illegal egg take, nesting rookery

\section{Introduction}

any marine turtle nesting rookeries in the Caribbean 1 have been reduced or extirpated by human exploitation (Parsons, 1962; Bjorndal \& Jackson, 2003; Bell et al., 2006; Bräutigam \& Eckert, 2006). Although a number of rookeries have been studied for several decades and their status is well documented (Dutton et al., 2005; Troëng \& Rankin, 2005; Richardson et al., 2006; Diez \& van Dam, 2007; Beggs et al., 2007), many other Caribbean rookeries

OHIANa Revuelta (Corresponding author), JuAn A. Raga and Jesús TOMÁs Cavanilles Institute of Biodiversity and Evolutionary Biology, University of Valencia, P.O. Box 22085, E-46071 Valencia, Spain. E-mail ohiana. revuelta@uv.es

Yolanda M. LeóN* and PABlo Feliz Grupo Jaragua, El Vergel, Santo Domingo, Dominican Republic

BRendan J. Godley Centre for Ecology and Conservation, School of Biosciences, University of Exeter Cornwall Campus, Penryn, UK

*Also at: Instituto Tecnológico de Santo Domingo, Urb. Galá, Santo Domingo, Dominican Republic

Received 18 May 2011. Revision requested 5 July 2011

Accepted 28 July 2011 remain poorly described (McClenachan et al., 2006; Dow et al., 2007). The Dominican Republic is an area where information on marine turtle nesting activity is scarce and outdated. Unlike foraging habitats, which have been studied since 1996 (León \& Diez, 1999; León \& Bjorndal, 2002), the conservation status of nesting populations in the Dominican Republic has never been comprehensively assessed, although there have been suggestions that they are seriously threatened (Ottenwalder, 1981, 1987; Stam \& Stam, 1992; Dow et al., 2007).

The Dominican Republic has a long history of harvest of and commerce in marine turtles, which have constituted an important resource for coastal communities (Ottenwalder, 1981; Fleming, 2001; Mota \& León, 2003; Reuter \& Allan, 2006). Marine turtles are now legally protected and their trade banned in the country by laws dating from 1966 and recently confirmed through the 2005 Fisheries Law CODOPESCA (Dominican Council of Fisheries and Agriculture). Slaughter of leatherback turtles Dermochelys coriacea for their meat and eggs was widely recorded in the 1980s (Ottenwalder, 1981; Ross \& Ottenwalder, 1983) and juvenile and adult green Chelonia mydas and hawksbill turtles Eretmochelys imbricata were exploited for their meat, eggs, shell and other products (Ottenwalder, 1981; Dominguez \& Villalba, 1994; Mota \& León, 2003). By the 1980 s it was estimated that 1,000-2,000 turtles were taken annually, of which $70 \%$ were green and hawksbill turtles and 30\% loggerhead Caretta caretta and leatherback turtles (Ottenwalder, 1996). Most of these turtles were caught by divers or taken incidentally in seine nets but many were captured from beaches whilst nesting. Despite legislation banning trade in tortoiseshell, an estimated $600 \mathrm{~kg}$ of hawksbill shell were used annually in the Dominican Republic in the 1980s (Ottenwalder, 1987). Between 1970 and 1986, Japanese customs data indicate that a total of 4,366 kg of hawksbill shell were exported to Japan (Fleming, 2001). Domestically, sale of items made from tortoiseshell has been reported more recently (Mota \& León, 2003; Reuter \& Allan, 2006; Feliz et al., 2010).

The Dominican Republic receives four million visitors annually, and this mass tourism has resulted in degradation of coastal habitats (León, 2004; Wielgus et al., 2010). Between 1980 and 1996 seven major coastal areas, including a large proportion of the most important turtle nesting habitat, were developed (Ottenwalder, 1996). By the 1980s six marine protected areas had been established, four of which (Montecristi, Del Este, La Caleta and Jaragua 
National Parks) cover c. 22\% of the coastline. There are nine coastal parks managed by the National Parks Directorate and, although none of them were created specifically for protection of marine turtles, some provide nesting and foraging habitat for them. However, there is little information available on marine turtles nesting in these areas.

Surveys in the 1970 s and 1980 s previously constituted the main reference on the status of marine turtles in the Dominican Republic (Ottenwalder, 1981; Ross \& Ottenwalder, 1983). Based on a combination of five countrywide aerial surveys conducted in April-July 1980, interviews with fisherman and local people, and nonintensive beach surveys, Ottenwalder (1981) estimated 420 (range 240-600) hawksbill, 380 (range 253-507) leatherback, 260 (range 160-360) green and 60 (range 30-90) loggerhead turtles nesting annually. Ross \& Ottenwalder (1983) identified four areas of special interest for nesting leatherback turtles: the beaches of San Luis and Bahía de las Águilas in Jaragua National Park in the south-west and Del Muerto and Macao beaches on the east coast. More recently leatherback turtle nesting has been recorded on the eastern beaches of Jaragua National Park during irregular beach walks during April-June (Dominici, 1996).

The lack of comprehensive studies and recent information and the threatened status of marine turtles in the Dominican Republic necessitated an updated assessment to help target effective conservation action. Our study had three main objectives: (1) to present the first systematic assessment in 30 years of the status of marine turtles nesting in the entire Dominican Republic based on 5 years (20062010) of systematic surveys, (2) to identify the main nesting rookeries and describe the current spatio-temporal patterns of nesting, and (3) to assess the likely impact of the current threats to these nesting stocks.

\section{Study area}

The Dominican Republic is in the eastern part of the Caribbean island of Hispaniola, which it shares with Haiti. It has $1,389 \mathrm{~km}$ of shoreline of which c. $800 \mathrm{~km}$ are sandy beaches. In February 2006 beach surveys and interviews with local people were carried out on 31 beaches previously described as important nesting sites (Ottenwalder, 1981; Ross \& Ottenwalder, 1983). Following these surveys intensive sampling concentrated in the two areas where nesting still seemed to be significant: Jaragua National Park and Saona Island. Opportunistic surveys were conducted in other areas during 2006-2010 to detect any other potential nesting sites and to verify reports received during the study (Figs $1 \& 2$ ).

Jaragua National Park in the south-west covers $1,374 \mathrm{~km}^{2}$, of which $905 \mathrm{~km}^{2}$ comprises beaches and dunes. The westernmost beaches, Bahía de las Águilas (4.4 km long) and La Cueva $(2.5 \mathrm{~km})$, have fine-grained, coralline, white sand. Although these beaches have no infrastructure development, they receive $>24,000$ visitors per year (Wielgus et al., 2010). The easternmost beaches of San Luis $(11 \mathrm{~km})$, Mosquea $(3.3 \mathrm{~km})$ and Inglesa $(1.2 \mathrm{~km})$ are on the narrow area of land between Oviedo Lagoon and the Caribbean Sea (Fig. 1). Eastern beaches are wider than those in the west and have coarser, darker sand, a steeper slope and strong wave action, which contributes to the accumulation of large amounts of plastic and other debris on the beaches of San Luis and Mosquea (OR, YML, PF \& JT, pers. obs.). Six human settlements with a total population of c. 15,000 are located around the boundary of the Park.

Saona Island (a part of Del Este National Park) in the south-east has an area of $110 \mathrm{~km}^{2}$. The main nesting zones for marine turtles include 12 narrow, white sand beaches ( $15 \mathrm{~km}$ long in total) interspersed with rocky areas on the south and west of the island (Fig. 1). Access to some of these beaches by foot is difficult. There is one permanent human settlement on Saona, Mano Juan, with a population of c. 30o. Both Saona Island and Jaragua National Park are regularly visited by groups of itinerant fishermen for several days at a time.

\section{Methods}

Daytime surveys were undertaken on foot by researchers and trained local people on the beaches of Jaragua National Park and Saona during 2006-2010. In Jaragua National Park beaches were monitored during: (1) 15 April to 19 November 2006, (2) 17 March to 20 October 2007, (3) 7 March to 8 October 2008, (4) 14 March to 23 September 2009, and (5) 26 March to 9 September 2010. Until 2009 the eastern beaches of the Park were monitored weekly, with the exception of the remote Inglesa beach, which was monitored twice per month. In 2009 and 2010 Mosquea was monitored daily by government rangers. On the western beaches of the Park there were 3-4 daytime surveys per week but survey effort ensured the record of all nesting events every year. Other remote beaches at this site with low levels of nesting were also occasionally visited to confirm reports of nests from reliable informants, although these were few (16 clutches in 5 years). On these beaches successful nesting events and false crawls that had occurred since the previous visit were recorded.

On Saona Island surveys started in September 2006 and thus we do not include total nesting numbers for this location and year. Since 23 September 2006 four major areas (Fig. 1) were patrolled weekly throughout the year.

Surveys in other areas of the Dominican Republic were undertaken during 2006-2010. Visits, sporadic patrols and interviews were made in 11 areas of the northern coast in 2006, 2007 and 2008, and on six beaches of the eastern and southern coasts in 2008, 2009 and 2010 (Fig. 2). Reports 

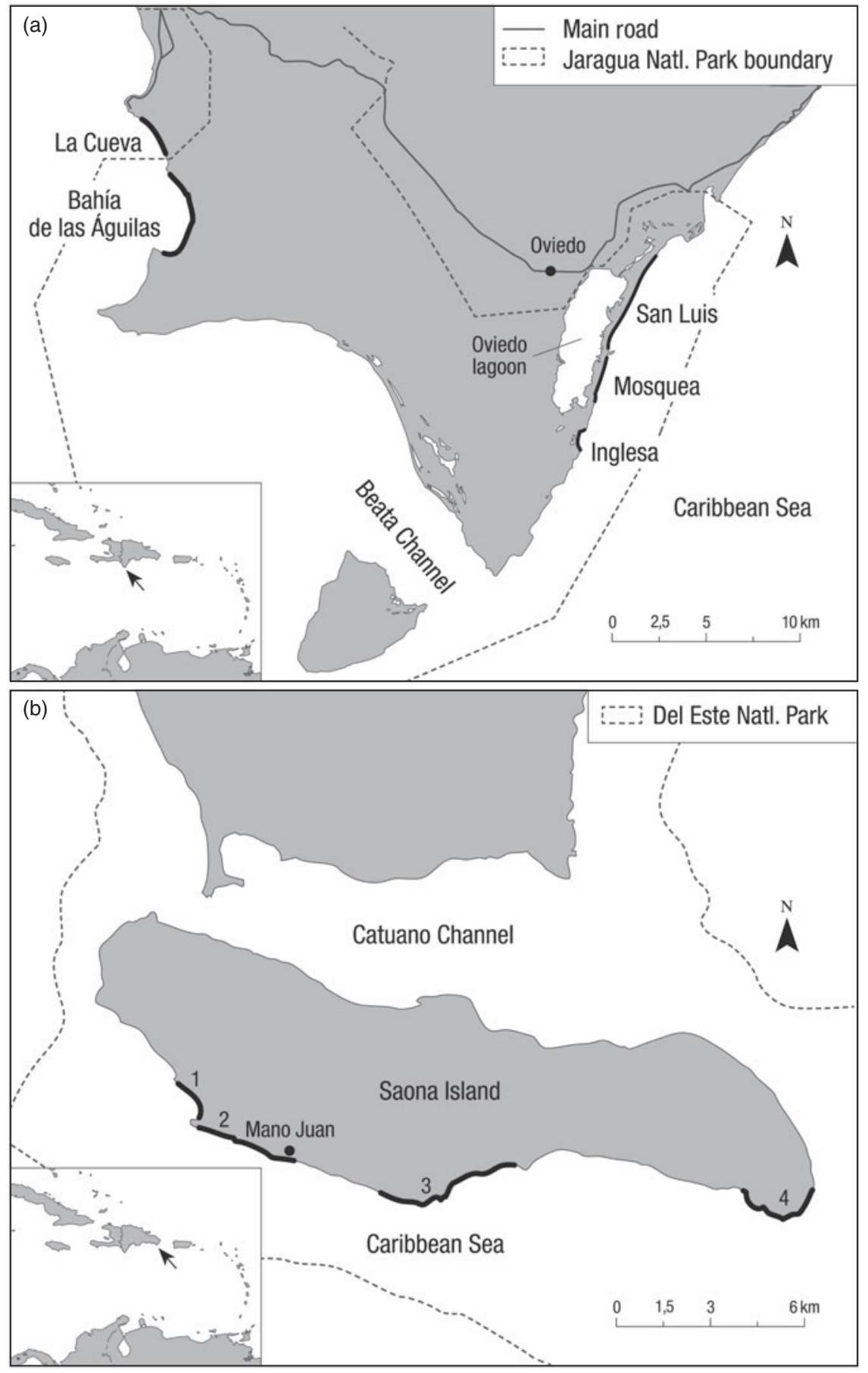

FIG. 1 The two main study areas of (a) Jaragua National Park, indicating the beaches of La Cueva and Bahía de las Águilas in the west and of San Luis, Mosquea and Inglesa in the east, and (b) Saona Island, indicating Mano Juan village and the four surveyed areas of (1) El Toro, (2) Mano Juan, (3) Canto la playa and (4) Faro Punta Cana. The insets indicate the location of the main maps in the Caribbean. about other nesting events, particularly from resorts or beach front developments, were also compiled.

During daytime surveys in Jaragua National Park and on Saona Island we recorded total number of emergences of nesting females. We identified the species based upon track characteristics (Schroeder \& Murphy, 1999) and confirmed whether each activity had successfully resulted in clutch deposition, by digging to find the clutch. Nest location was recorded using a global positioning system and turtle tracks were marked to avoid duplicate counts. Signs of eggs taken by people were recorded (presence of probing sticks, evidence of digging and broken eggshells, and/or human footprints around the nesting site; Troëng et al., 2004). Remaining clutches were either camouflaged and incubated under natural conditions on the beach, or clutches with high risk of subsequent take (because of proximity to a human settlement and the number of people in the area) were transferred to protected hatcheries for incubation in boxes. Because of funding limitations night surveys were only carried out on Saona Island and the western beaches of 


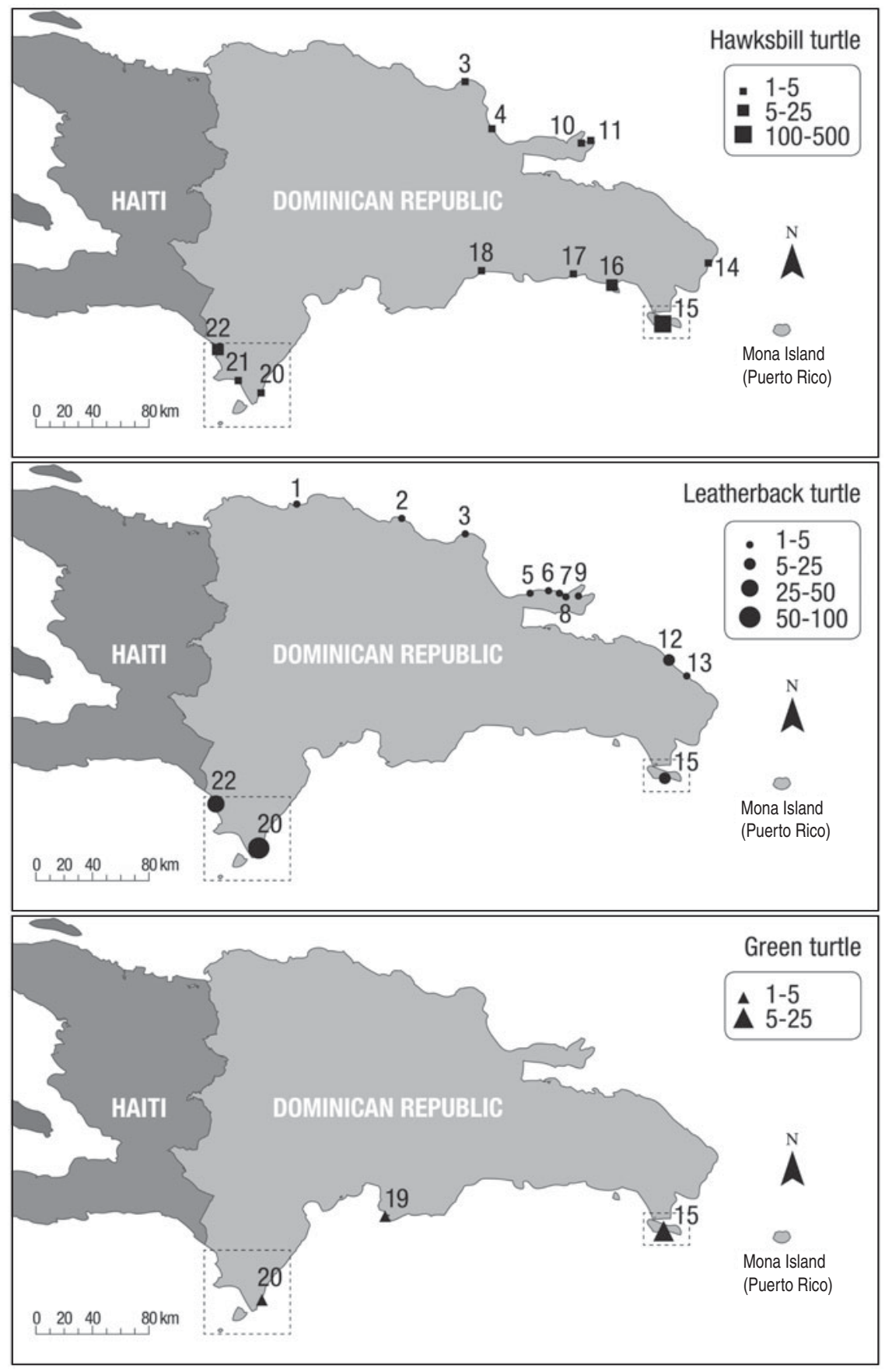

FIG. 2 Maximum number of confirmed nests of hawksbill Eretmochelys imbricata, leatherback Dermochelys coriacea and green Chelonia mydas marine turtles per year during 20062010. Numbers correspond to beach locations: (1) beaches on both sides of the Estero Hondo bay (Punta Rucia and Punta Burén), (2) Sosúa and Cabarete beaches (Puerto Plata province),

(3) Playa Grande, (4) Arroyo Salado,

(5) Cosón (bonita and Morón beaches),

(6) El Limón, (7) Lanza del Norte,

(8) El Valle, (9) Rincón, (10) Colorá,

(11) Las Galeras/Madama, (12) El Muerto/La Vacama, (13) Macao and Uvero Alto, (14) Punta Cana,

(15) southern Saona Island (several beaches), (16) Isla Catalina, (17) San Pedro de Macorís, (18) Guibia (Santo Domingo), (19) Salinas, (20) Oviedo Lagoon, (21) Beata Channel, and (22) La Cueva-Bahía. Dotted lines show the two main study areas: Jaragua National Park in the south-west and Saona Island in the south-east (part of Del Este National Park).
Jaragua National Park. To maximize the probability of finding nesting females during night surveys, we timed these surveys according to the inter-nesting intervals of the females. We collected data on clutch size and egg size and weight and measured the curved carapace length (CCL, from nuchal notch to the caudal tip of the carapace) and maximum curved carapace width (CCWmax) of nesting females. Leatherback females were tagged with large metal Inconel tags (National Brand and Tag Co., Newport, USA) fitted between the tail and rear flippers. Hawksbill females were tagged with small metal Inconel tags on the trailing edge of both fore-flippers.

\section{Results}

\section{Status and spatio-temporal distribution}

The surveys confirmed that leatherback, hawksbill and green turtles are nesting in the Dominican Republic. Nesting is concentrated in Jaragua National Park and on Saona Island. Nesting outside these areas was confirmed, through visits and interviews, to be relatively uncommon (Fig. 2).

The Jaragua National Park consistently had the highest number of clutches per year of leatherback turtles (mean $126.4 \pm$ SD 74.1, range 17-210), with a total of 632 clutches 


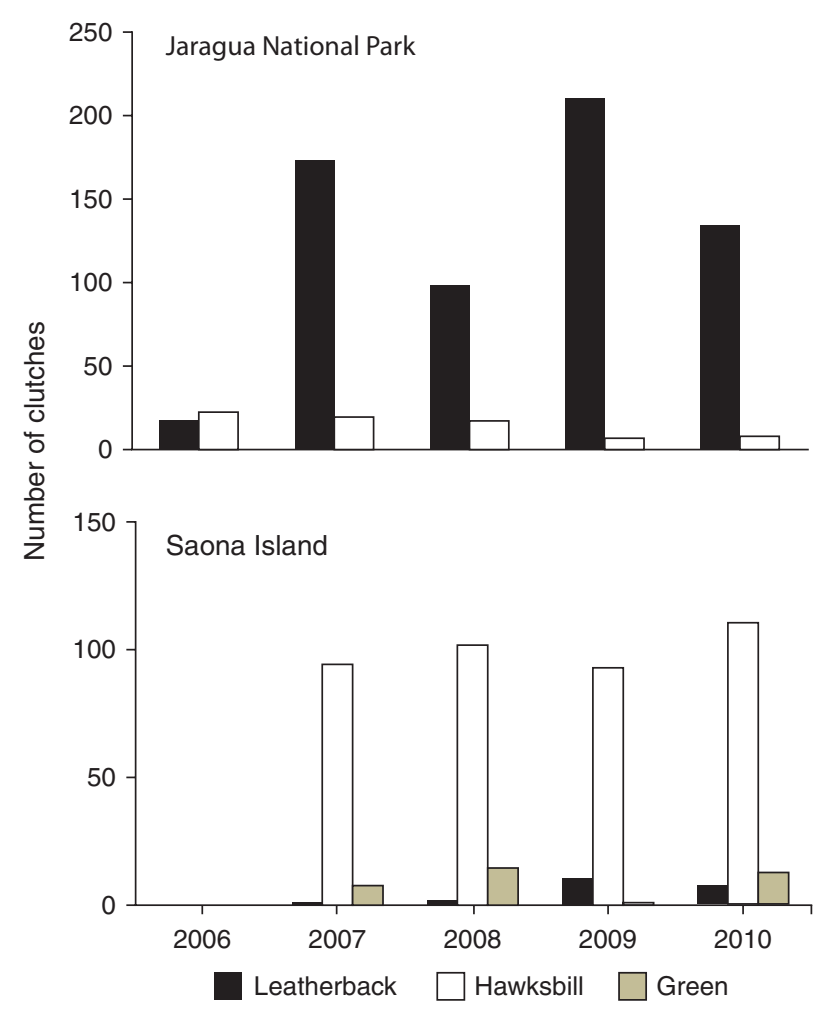

FIG. 3 Number of clutches of leatherback, hawksbill and green marine turtles per year in Jaragua National Park and on Saona Island. In 2007 one green turtle nest, which is not shown, was recorded in Jaragua National Park. Note the different y-axis scales.

recorded during 2006-2010 (Figs 2 \& 3). These values correspond to an estimated annual number of three, 33, 19, 40 and 25 females in each of the 5 years, respectively (based on a mean number of clutches per season of 5.26; Boulon et al., 1996). Hawksbill turtles nested in low numbers in the Park (mean $14.6 \pm$ SD 6.7 per year, range 7-22 clutches per year), with a total of 73 clutches recorded in the 5 years, mainly in the west (Fig. 2). The estimated annual number of hawksbill turtles was five, four, four, one and two nesting females in each of the 5 years, respectively (based on a mean number of clutches per season of 4.5; Richardson et al., 1999). We recorded only one confirmed clutch of green turtles in this area during the study period (Fig. 2).

Saona Island hosted the majority of recorded hawksbill (mean $100 \pm$ SD 8.4 per year, range 93-111, total 400) and green turtle clutches (mean 9.2 \pm SD 6.2, range 1-15, total 37 ) but only 22 leatherback turtle clutches were recorded (mean $5.5 \pm$ SD 4.8, range 1-11). The annual number of hawksbill turtle clutches recorded was similar among years (Fig. 3 ) and the estimated annual number of hawksbill females nesting in each year was $21,23,23$ and 25 in 2007-2010, respectively.

Elsewhere 1-5 hawksbill turtle nests per year were reported on the Punta Cana and Cap Cana beach resort on the east coast. The only beach outside the two main nesting areas that seems to host significant leatherback turtle nesting is El Muerto beach (Fig. 2). In 2009 we recorded 12 recent nests there. Local people reported nine nests later in the same season. This area merits future monitoring. The northern coast of Samaná Peninsula seems regularly to have a low number of nests (1-3 clutches per beach and year) of hawksbill and leatherback turtles, and merits further surveys.

\section{Seasonality}

In Jaragua National Park the nesting period of leatherback turtles extended from March to August, with most emergences occurring in April-June (89.6\% of nests). The highest number of emergences was in May (mean number of nests $64 \pm$ SD 12.7). Because of the low level of nesting by hawksbill turtles in the Park it is difficult to ascertain seasonality for this species there, although nesting appears to be higher in July (Fig. 4). On Saona Island hawksbill turtles were observed nesting in every month of the year, although most nesting occurred in June-November (71.2\% of the nests) and low levels of nesting were observed in December-May (Fig. 4). The green turtle appears to have a shorter nesting season, from July to November, with a possible peak in August. However, any seasonality in the nesting of this species is unclear because of the low number of nests observed. The three species nested mainly at night although there were two records of hawksbill turtles nesting diurnally on Saona Island.

\section{Morphometrics and reproductive data}

Biometric parameters of leatherback and hawksbill turtles are given in Table 1. All leatherback females encountered on western beaches of Jaragua National Park in 2006-2010 were tagged. We recorded four reproductive females (30.8\%) with a CCL $(132,135,138$ and $143 \mathrm{~cm})$ below the threshold carapace length for adult classification in leatherback turtles (145 cm; Eckert, 2002; James et al., 2007). Mean clutch sizes (yolked eggs) of leatherback turtles recorded in the Park were 68.7 \pm SD $18.1(n=64), 72.4 \pm S D 15.5$ $(\mathrm{n}=59), 75.1 \pm$ SD $17.3(\mathrm{n}=125)$ and $67.5 \pm$ SD 17.8 eggs $(\mathrm{n}=67)$ in 2007-2010, respectively.

On Saona Island seven female hawksbill turtles were tagged in 2008, five in 2009 and seven in 2010 (Table 1). Mean clutch sizes of hawksbill turtles on Saona Island were $125.7 \pm \operatorname{SD} 23.3(\mathrm{n}=29), 132.4 \pm \operatorname{SD} 29.9(\mathrm{n}=55)$, $138.4 \pm$ SD $23.2(n=40)$ and $139.5 \pm S D 29(n=55)$ in 20072010, respectively.

\section{Assessment of threats}

Illegal taking of eggs was identified as the main threat to the marine turtles (Table 2). The highest level of egg-take 
TABLE 1 Morphometric and reproductive parameters of leatherback Dermochelys coriacea and hawksbill Eretmochelys imbricata turtles nesting at Jaragua National Park and Saona Island in the Dominican Republic (Fig. 1).

\begin{tabular}{|c|c|c|c|c|c|c|}
\hline \multirow[b]{2}{*}{ Parameter } & \multicolumn{3}{|c|}{ Leatherback (Jaragua National Park) } & \multicolumn{3}{|c|}{ Hawksbill (Saona) } \\
\hline & $\mathrm{N}$ & Mean \pm SD & Range & $\mathrm{N}$ & Mean \pm SD & Range \\
\hline Curved carapace length $(\mathrm{cm})$ & 13 & $147.4 \pm 8.7$ & $132-162$ & 19 & $87.2 \pm 4.7$ & $81-96$ \\
\hline Curved carapace width $(\mathrm{cm})$ & 13 & $107.7 \pm 5.1$ & $100-118$ & 15 & $77.1 \pm 4.2$ & $71-84$ \\
\hline Clutch size (no. of yolked eggs) & 315 & $71.7 \pm 17.5$ & $10-128$ & 179 & $134.8 \pm 27.5$ & $82-235$ \\
\hline Egg size $(\mathrm{mm})$ & 740 & $5.2 \pm 0.2$ & $4.5-5.7$ & 380 & $3.4 \pm 0.09$ & $3.1-3.8$ \\
\hline Egg mass (g) & 500 & $85.4 \pm 8.7$ & $65.5-102.4$ & 240 & $29.9 \pm 2.3$ & $24.5-85.4$ \\
\hline
\end{tabular}

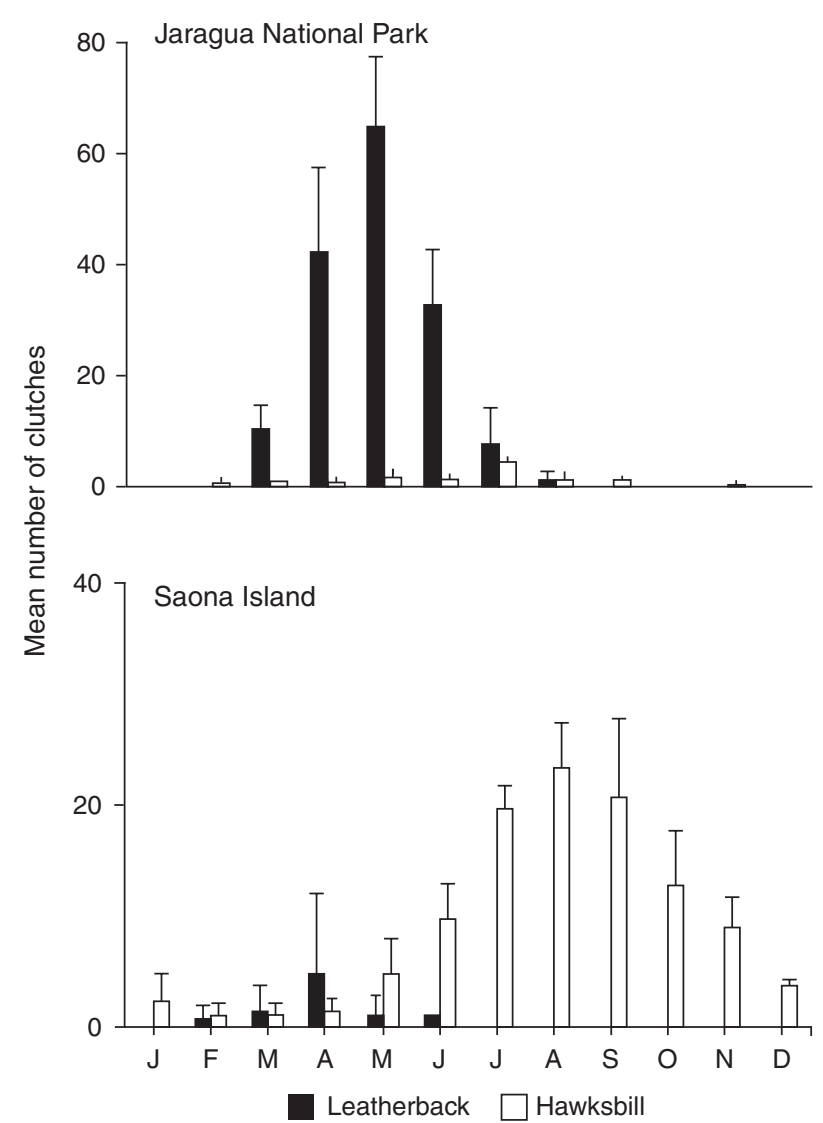

FIG. 4 Mean $( \pm S D)$ number of clutches per month of leatherback and hawksbill marine turtles for 2006-2010 in Jaragua National Park, and for 2007-2010 on Saona Island. Note the different y-axis scales.

was from the eastern beaches of Jaragua National Park. All clutches laid by hawksbill and leatherback turtles on Inglesa beach were taken by humans. Overall $88.9 \%$ of hawksbill clutches laid on Mosquea and San Luis beaches during the study period were taken and only a small percentage of leatherback clutches were incubated on the beach $(1 \%$ in 2007 and $8.4 \%$ in 2009); the remainder were relocated to a protected hatchery for artificial incubation or otherwise taken by humans. The percentage of leatherback turtle clutches taken on the beaches of Bahía de las Águilas and La Cueva in the west of the Park was lower than on the eastern beaches, with $75.9 \%$ of 290 clutches incubated naturally during the study period. However, take of hawksbill turtle clutches was high every year (Table 2).

We found hawksbill and green turtle carcasses, bones and scutes from both adults and juveniles in Jaragua National Park and on Saona Island, which we presume to be remains, at least in part, from illegal take. Meat and eggs are consumed and illegally sold in local markets (YML \& JT, pers. obs.). Throughout the study period no reported cases of consumption of leatherback meat were recorded.

\section{Discussion}

For the first time in recent decades we have documented the presence of three marine turtle species (hawksbill, leatherback and green) nesting in the Dominican Republic. Comparison of our results with early reports (Ottenwalder, 1981; Ross \& Ottenwalder, 1983) indicates that a profound decline appears to have taken place in the last 30 years. Nesting has largely been reduced to the undeveloped, protected areas of Jaragua National Park and Saona Island. However, there are still high rates of human exploitation of eggs and at least some take of turtles in these protected areas.

The number of clutches of hawksbill and green turtles, which we found mainly on Saona Island, are low compared to estimates of 400 hawksbill and 260 green turtles nesting per year throughout the country in the $1980 \mathrm{~s}$ (Ottenwalder, 1981). Ross \& Ottenwalder (1983) suggested that 300 leatherback turtles were nesting annually in the Dominican Republic, based on one aerial survey, 24 interviews and a few beach surveys between 24 March and 13 April 1980. Based on 5 years of systematic surveys we have estimated that a maximum of 40 leatherback females currently nest in Jaragua National Park per year, with no more than 50 in the country. Of further concern was our failure to detect loggerhead turtles nesting, even though Ottenwalder (1981) estimated c. 60 females were nesting per year.

Our findings seem to indicate that there has been a marked reduction in the abundance of the four species throughout the country since the 1980s. However, there 
TABLE 2 Total numbers and percentage of hawksbill, leatherback and green Chelonia mydas turtle clutches recorded in Jaragua National Park and Saona Island during 2006-2010 that were subject to human take, translocated to a breeding facility, or incubated on the beach under natural conditions.

\begin{tabular}{|c|c|c|c|c|c|c|c|c|c|c|c|c|}
\hline \multirow[b]{2}{*}{$\begin{array}{l}\text { Year (by } \\
\text { location) }\end{array}$} & \multicolumn{4}{|c|}{ Leatherback } & \multicolumn{4}{|c|}{ Hawksbill } & \multicolumn{4}{|l|}{ Green } \\
\hline & Total & $\begin{array}{l}\text { Human take } \\
(\%)\end{array}$ & $\begin{array}{l}\text { Translocated } \\
(\%)\end{array}$ & $\begin{array}{l}\text { Beach } \\
(\%)\end{array}$ & Total & $\begin{array}{l}\text { Human take } \\
(\%)\end{array}$ & $\begin{array}{l}\text { Translocated } \\
(\%)\end{array}$ & $\begin{array}{l}\text { Beach } \\
(\%)\end{array}$ & Total & $\begin{array}{l}\text { Human take } \\
(\%)\end{array}$ & $\begin{array}{l}\text { Translocated } \\
(\%)\end{array}$ & $\begin{array}{l}\text { Beach } \\
(\%)\end{array}$ \\
\hline \multicolumn{13}{|c|}{ Jaragua National Park (west) } \\
\hline 2006 & 2 & 50 & 0 & 50 & 22 & 68.1 & 27.2 & 4.5 & & & & \\
\hline 2007 & 59 & 37.3 & 10.2 & 52.5 & 14 & 71.4 & 28.6 & 0 & 1 & 0 & 100 & 0 \\
\hline 2008 & 63 & 1.6 & 34.9 & 63.5 & 15 & 33.3 & 66.7 & 0 & & & & \\
\hline 2009 & 83 & 4.8 & 16.9 & 78.3 & 4 & 25 & 50 & 25 & & & & \\
\hline 2010 & 83 & 0 & 0 & 100 & 8 & 37.5 & 12.5 & 50 & & & & \\
\hline \multicolumn{13}{|c|}{ Jaragua National Park (east) } \\
\hline \multicolumn{13}{|c|}{ Mosquea-San Luis } \\
\hline 2006 & 7 & 42.8 & 57.1 & 0 & & & & & & & & \\
\hline 2007 & 102 & 48.0 & 51.0 & 1 & 4 & 75 & 0 & 25 & & & & \\
\hline 2008 & 29 & 44.8 & 55.2 & 0 & 2 & 100 & 0 & 0 & & & & \\
\hline 2009 & 119 & 23.5 & 68.1 & 8.4 & 3 & 100 & 0 & 0 & & & & \\
\hline 2010 & 39 & 46.1 & 51.3 & 2.6 & & & & & & & & \\
\hline \multicolumn{13}{|l|}{ Inglesa } \\
\hline 2006 & 8 & 100 & 0 & 0 & & & & & & & & \\
\hline 2007 & 12 & 100 & 0 & 0 & 1 & 100 & 0 & 0 & & & & \\
\hline 2008 & 6 & 100 & 0 & 0 & & & & & & & & \\
\hline 2009 & 8 & 100 & 0 & 0 & & & & & & & & \\
\hline 2010 & 12 & 100 & 0 & 0 & & & & & & & & \\
\hline \multicolumn{13}{|l|}{ Saona } \\
\hline 2007 & 1 & 100 & 0 & 0 & 94 & 56.4 & 21.3 & 22.3 & 8 & 37.5 & 37.5 & 25 \\
\hline 2008 & 2 & 50 & 50 & 0 & 102 & 32.3 & 50 & 17.6 & 15 & 13.3 & 73.3 & 13.3 \\
\hline 2009 & 11 & 72.7 & 9.1 & 18.2 & 93 & 50.5 & 41.9 & 7.5 & 1 & 0 & 100 & 0 \\
\hline 2010 & 8 & 75 & 25 & 0 & 111 & 17.2 & 46.8 & 36.0 & 13 & 7.7 & 38.5 & 53.8 \\
\hline
\end{tabular}


are some caveats regarding the previous estimates. Firstly, data reported by Ottenwalder (1981) were based on 2 years of non-intensive monitoring and interviews. Secondly, loggerhead turtles are considered to nest infrequently in the Caribbean (Ehrhart et al., 2003; Dow et al., 2007), and Ottenwalder noted that, in interviews, many fishermen confused this species with others. It is therefore possible that the number of loggerhead turtles nesting was previously overestimated, as is thought to have occurred in similar studies based on interview data in the region (Richardson et al., 2009). Thirdly, the decline of the leatherback turtle nesting rookeries in the Dominican Republic could be because of a shift of nesting to nearby rookeries, as this species has low nest site fidelity (Georges et al., 2007; Troëng et al., 2007). The leatherback turtle population in the Dominican Republic possibly forms part of a wider regional nesting stock, as has been suggested for other rookeries in the Antilles (Dutton et al., 2005). Despite these caveats it is probable that harvesting of eggs and females from beaches and the trade in marine turtles documented in the Dominican Republic (Ottenwalder, 1996; Fleming, 2001; Reuter \& Allan, 2006) has contributed significantly to the decline of these turtle populations. However, we cannot refute the possibility that numbers of all three turtle species nesting in the Dominican Republic, particularly the leatherback and hawksbill, were lower in previous years and are beginning, as in some Caribbean range states, to increase (Dutton et al., 2005; Troëng \& Rankin, 2005; Richardson et al., 2006).

According to Ottenwalder (1981) hawksbill turtles nested in the past in significant numbers on beaches around the entire coast of the Dominican Republic and green turtles nested every night on northern beaches. Currently, only the relatively unspoilt beaches of Saona Island, in Del Este National Park, provide major nesting areas for hawksbill and green turtles. Nesting of leatherback turtles previously occurred on the northern and eastern coasts, and the beaches of Macao and El Muerto in La Altagracia province on the eastern coast hosted 2-3 females nightly during the nesting season in the 1980s (Ross \& Ottenwalder, 1983). Significant nesting by leatherback turtles occurs only on the isolated beaches of Jaragua National Park, where access for people is difficult and there is no coastal development. In addition to the taking of eggs and adults on beaches near habitation, habitat has been lost to intensive coastal development during the last 30 years (Ottenwalder, 1981; León, 2004; Wielgus et al., 2010). Currently, the northern and eastern coasts have the most tourism infrastructure and we detected only sporadic nesting events on these beaches.

Despite the importance of coastal and marine protected areas as refuges for marine biodiversity in the country we observed that there is little actual protection and inadequate management by local authorities (OR, YML, PF \& JT, pers. obs.). Our results highlight the need for adequate protection and management of these areas for marine turtle conservation, especially considering that Jaragua National Park also hosts important foraging habitats for Caribbean hawksbill and green turtles (León \& Diez, 1999; León \& Bjorndal, 2002).

Items made from tortoiseshell were previously widely available in tourist gift shops in the Dominican Republic (Ottenwalder, 1996; Mota \& León, 2003; Reuter \& Allan, 2006; Feliz et al., 2010). However, since 2009 the environmental authorities have conducted several seizures of tortoiseshell items in the gift shops of Santo Domingo, resulting in a significant reduction in the sale of such items (OR, YML \& PF, pers. obs.).

Our study has shown that the leatherback turtle nesting season is from March to August, with a peak in May, consistent with reports for neighbouring nesting populations (Dutton et al., 2005; Hilterman \& Goverse, 2007; McGowan et al., 2008). The seasonality of hawksbill turtle nesting is similar to nearby rookeries on Antigua, Barbados and Mona Island, Puerto Rico (Richardson et al., 1999; Beggs et al., 2007; Diez \& van Dam, 2007).

The differences in nesting activity between the two main nesting areas may be explained by species' preferences. Leatherback turtles tend to use high energy beaches with deep water nearby, free of obstructions and often with a windward orientation (Mrosovsky, 1983; Eckert, 1987). This description fits the eastern beaches of Jaragua National Park, which is the most important nesting area for the species in the country. Hawksbill turtles, however, often swim over reefs and through shallow waters with lower wave energy to reach beaches with dense vegetation (Horrocks \& Scott, 1991). This description fits all of the Saona Island beaches and most of the western beaches of Jaragua National Park.

The mean CCL $(147.4 \mathrm{~cm})$ of leatherback turtles in the Dominican Republic is lower than the global mean, which is normally distributed around $155 \mathrm{~cm}$ (see review in Stewart et al., 2007) and we confirmed the viability of clutches of females that are below the minimum size of sexual maturity reported elsewhere (e.g. Eckert, 2002). We are confident that our results are not measurement errors because we used standard measurements (Bolten, 1999) and the carapaces had no deformities or injuries. This could be the sign of a recovering population with a high proportion of neophyte females. However, reduction in the size of nesting females can be caused by intensive capture of turtles either in the foraging areas or in the same nesting areas (Bjorndal et al., 1985; Limpus et al., 2003). The mean CCL of nesting hawksbill turtles in the Dominican Republic is similar to the mean CCL in other Caribbean regions. However, the CCL of 11 hawksbill females measured on Saona Island was within the CCL range recorded for neophytes in Buck Island, US Virgin Islands (82.1-88 cm, Garland \& Hillis-Starr, 2003). 
This research has filled a significant gap in knowledge of the population status and conservation of marine turtles in the Caribbean (Dow et al., 2007). Many of the large turtle rookeries in the region are the subject of ongoing long-term monitoring and conservation programmes. Although several appear to be showing signs of recovery (St Croix, US Virgin Islands, Dutton et al., 2005; Barbados, Beggs et al., 2007; Mona Island in Puerto Rico, Diez \& van Dam, 2007) this is not the case for all turtle rookeries in the region.

To facilitate effective marine turtle conservation across the Caribbean conservation programmes need to focus on sites that were formerly important nesting areas (McClenachan et al., 2006). Our results suggest this is the case in the Dominican Republic, which therefore warrants increased attention at the regional level, particularly for the hawksbill turtle. Molecular and genetic techniques have provided insights into patterns of migration, stock differentiations, and links between nesting beaches and foraging grounds of the hawksbill turtle in the Caribbean (Bowen et al., 2007; Blumenthal et al., 2009). Recovery will therefore depend on actions both in the Dominican Republic and in the wider Caribbean.

The fact that nesting activity is concentrated in protected areas provides an opportunity to implement specific actions for protection and management of the rookeries (Santidrián Tomillo et al., 2008). We conclude that to improve marine turtle conservation in the Dominican Republic it is necessary to promote the effective management of existing protected areas, including nesting beaches for marine turtles, to promote the management of coastal development to avoid further loss of nesting beaches, and to support the enforcement and efficient implementation of laws to reduce take of marine turtles and their eggs.

\section{Acknowledgements}

The present study is part of a conservation project funded by the Spanish International Cooperation Agency (AECI, projects $\mathrm{A} / 2991 / 05$ and $\mathrm{A} / 5641 / 06$ ), the Spanish Ministry of Education and Sciences (CGL2006-02936-BOS and CGL2011-30413), the General Foundation of the University of Valencia, a special action of the same University (UVINV-AE11-42960), and the European Union (Marie Curie grants, FP6 and 7). We thank the Dominican NGO Grupo Jaragua and The Nature Conservancy. The project counts on the support of the Dominican Environmental authorities (Office of Protected Areas and Biodiversity of the Environmental Ministry) and the rangers of the National Parks. We are grateful to our assistants in Jaragua National Park, Bienvenido Pérez Turbí 'Blanco' and the rangers for their work, and especially to Pelagio Paulino 'Negro' for his help during fieldwork on Saona Island and his work for the conservation of marine turtles. We extend our thanks to the Dominican and international students, volunteers and villagers for their help and friendship during the field work.

\section{References}

Beggs, J.A., Horrocks, J.A. \& Krueger, B.H. (2007) Increase in hawksbill sea turtle Eretmochelys imbricata nesting in Barbados, West Indies. Endangered Species Research, 3, 159-168.

Bell, C.D., Blumenthal, J.M., Austin, T.J., Solomon, J.L., Ebanks-Petrie, G., Broderick, A.C. \& Godley, B.J. (2006) Traditional Caymanian fishery may impede local marine turtle population recovery. Endangered Species Research, 2, 63-69.

Bjorndal, K.A., Carr, A., Meylan, A.B. \& Mortimer, J.A. (1985) Reproductive biology of the hawksbill turtle Eretmochelys imbricata at Tortuguero, Costa Rica, with notes on the ecology of the species in the Caribbean. Biological Conservation, 34, 353-368.

BJorndal, K.A. \& JACKSON, J.B.C. (2003) Roles of sea turtles in marine ecosystems: reconstructing the past. In The Biology of Sea Turtles, Volume II (eds P.L. Lutz, J.A. Musick \& J. Wyneken), pp. 259-273. CRC Press, Boca Raton, USA.

Blumenthal, J.M., Abreu-Grobois, F.A., Austin, T.J., Broderick, A.C., Bruford, M.W., Coyne, M.S. et al. (2009) Turtle, groups or turtle soup: dispersal patterns of hawksbill turtles in the Caribbean. Molecular Ecology, 18, 4841-4853.

Bolten, A.B. (1999) Techniques for measurement of sea turtles. In Research and Management Techniques for the Conservation of Sea Turtles (eds K.L. Eckert, K.A. Bjorndal, F.A. Abreu-Grobois \& M. Donelly), pp. 110-114. IUCN/Species Survival Commission Marine Turtle Specialist Group Publication No. 4, Blanchard, USA. Boulon, R.H., Dutton, P.H. \& McDonald, D.L. (1996) Leatherback turtles (Dermochelys coriacea) on St. Croix, US Virgin Islands: fifteen years of conservation. Chelonian Conservation and Biology, 2, 141-147.

Bowen, B.W., Grants, W.S., Hillis-Star, Z., Shaver, D.J., Bjorndal, K.A., Bolten, A.B. \& Bass, A.L. (2007) Mixed stock analysis reveals the migrations of juvenile hawksbill, Eretmochelys imbricata, in the Caribbean Sea. Molecular Ecology, 16, 49-60.

Bräutigam, A. \& Eckert, K.L. (2006) Turning the Tide: Exploitation, Trade and Management of Marine Turtles in the Lesser Antilles, Central America, Colombia and Venezuela. TRAFFIC International, Cambridge, UK.

Diez, C.E. \& VAN DAM, R.P. (2007) Mona and Monito Island-Puerto Rico Hawksbill Turtle Research Project: Research Report for 2006. Unpublished Technical Report. Mona Island Hawksbill Research Group in collaboration with Departamento de Recursos Naturales y Ambientales de Puerto Rico, Chelonia, Inc., and Universidad de Puerto Rico, Rio Piedras, Puerto Rico.

Dominguez, T.J. \& Villalba, A.A. (1994) Trade of hawksbill carapaces in Santo Domingo, Dominican Republic. In Proceedings of the Fourteenth Annual Symposium on Sea Turtle Biology and Conservation (eds K.A. Bjorndal, A.B. Bolten, D.A. Johnson \& P.J. Eliazar), pp. 34-35. Hilton Head, South Carolina, USA.

Dominici, G.O. (1996) Monitoreo de anidamiento de tortuga tinglar Dermochelys coriacea en playas del Parque Nacional Jaragua. In Memorias del II congreso de la Biodiversidad Caribeña, Santo Domingo, Dominican Republic.

Dow, W., Eckert, K., Palmer, M. \& Kramer, P. (2007) An Atlas of Sea Turtle Nesting Habitat for the Wider Caribbean Region. 
WIDECAST Technical Report No. 6. The Wider Caribbean Sea Turtle Conservation Network and The Nature Conservancy, Beauford, USA.

Dutton, D.L., Dutton, P.H., Chaloupka, M. \& Boulon, R.H. (2005) Increase of a Caribbean leatherback turtle Dermochelys coriacea nesting population linked to long-term nest protection. Biological Conservation, 126, 186-194.

ECKERT, K.L. (1987) Environmental unpredictability and leatherback sea turtle (Dermochelys coriacea) nest loss. Herpetologica, 43, 315-323.

ECKerT, S.A. (2002) Distribution of juvenile leatherback sea turtle Dermochelys coriacea sightings. Marine Ecology Progress Series, 230, 289-293.

Ehrhart, L.M., Bagley, D.A. \& Redfoot, W.E. (2003) Loggerhead turtles in the Atlantic Ocean: geographic distribution, abundance, and population status. In Loggerhead Sea Turtles (eds A.B. Bolten \& B.E. Witherington), pp. 157-174. Smithsonian Institution, Washington, DC, USA.

Feliz, P., León, Y.M., Tomás, J., Hierro, K., Mateo, A., Méndez, M.D. \& RAGA, J.A. (2010) Tortoiseshell trade in Santo Domingo, Dominican Republic: discouraging news for Caribbean hawksbill. In Proceedings of the Twenty-Eighth Annual Workshop on Sea Turtle Biology and Conservation (eds K. Dean \& M.C. López Castro), pp. 247. National Oceanic and Atmospheric Administration, Miami, USA.

Fleming, E.H. (2001) Swimming Against the Tide: Recent Surveys of Exploitation, Trade, and Management of Marine Turtles in the Northern Caribbean. TRAFFIC North America, Washington, DC, USA.

Garland, K. \& Hillis-Starr, Z. (2003) Carapace characteristics of hawksbills (Eretmochelys imbricata) at Buck Island National Monument, US Virgin Islands: long term remigrants vs neophytes. In Proceedings of the Twenty-Second Annual Symposium on Sea Turtle Biology and Conservation (ed. J.A. Seminoff), pp. 286. National Oceanic and Atmospheric Administration, Miami, USA.

Georges, J.Y., Fossette, S., Billes, A., Ferraroli, S., Fretey, J., Grémillet, D. et al. (2007) Meta-analysis of movements in Atlantic leatherback turtles during the nesting season: conservation implications. Marine Ecology Progress Series, 338, 225-232.

Hilterman, M. \& Goverse, E. (2007) Nesting and nest success of the leatherback turtle (Dermochelys coriacea) in Suriname, 1999-2005. Chelonian Conservation and Biology, 6, 87-100.

Horrocks, J.A. \& Sсотт, N.M. (1991) Nest site location and nest success in the hawksbill turtle Eretmochelys imbricata in Barbados, West Indies. Marine Ecology Progress Series, 69, $1-8$.

James, M.C., Sherrill-Mix, S.A. \& Myers, R.A. (2007) Population characteristics and seasonal migrations of leatherback sea turtles at high latitudes. Marine Ecology Progress Series, 337, 245-254.

LEÓN, Y.M. (2004) Community Impacts of Coastal Tourism in the Dominican Republic. PhD thesis. University of Rhode Island, Kingston, USA.

LEÓN, Y.M. \& BJORNDAL, K.A. (2002) Selective feeding in the hawksbill turtle, an important predator in coral reef ecosystems. Marine Ecology Progress Series, 245, 249-258.

LEÓN, Y.M. \& DieZ, C.E. (1999) Population structure of hawksbill turtles on a foraging ground in the Dominican Republic. Chelonian Conservation and Biology, 3, 230-236.

Limpus, C.J., Miller, J., Parmenter, C. \& Limpus, D. (2003) The green turtle, Chelonia mydas, population of Raine Island and the northern Great Barrier Reef 1843-2001. Memoirs of the Queensland Museum, 49, 349-440.

McClenachan, L., Jackson, J. \& Newman, M. (2006) Conservation implications of historic sea turtle nesting beach loss. Frontiers in Ecology and the Environment, 4, 290-296.

McGowan, A., Broderick, A.C., Frett, G., Gore, S., Hastings, M., Pickering, A. et al. (2008) Down but not out: marine turtles of the British Virgin Islands. Animal Conservation, 11, 92-103.

Mota, J.M. \& LeÓN, Y.M. (2003) Beliefs and perceptions associated with sea turtle products in the Dominican Republic. In Proceedings of the Twenty-Third Annual Symposium on Sea Turtle Biology and Conservation (ed. N.J. Pilcher), pp. 197-199. Kuala Lumpur, Malaysia.

Mrosovsky, N. (1983) Ecology and nest-site selection of leatherback turtles, Dermochelys coriacea. Biological Conservation, 26, 47-56.

Ottenwalder, J.A. (1981) Estudio preliminar sobre el estado, distribución, y biología reproductiva de las tortugas marinas en la República Dominicana. Tesis de Licenciatura, Universidad Autónoma de Santo Domingo, Dominican Republic.

Ottenwalder, J.A. (1987) National Report for Dominican Republic. Western Atlantic Symposium II, Mayagüez, Puerto Rico, September 1987. WATS2-072. Unpublished.

Ottenwalder, J.A. (1996) Conservation and Management of Sea Turtles in the Dominican Republic. Unpublished Report.

Parsons, J.J. (1962) The Green Turtle and Man. University of Florida Press, Gainesville, USA.

Reuter, A. \& Allan, C. (2006) Tourists, Turtles and Trinkets: A Look at the Trade in Marine Turtle Products in the Dominican Republic and Colombia. TRAFFIC North America, Washington, DC, USA.

Richardson, J.I., Bell, R. \& Richardson, T.H. (1999) Population ecology and demographic implications drawn from an 11-year study of nesting hawksbill turtles, Eretmochelys imbricata, at Jumby Bay, Long Island, Antigua, West Indies. Chelonian Conservation and Biology, 3, 244-250.

Richardson, J.I., Hall, D.B., Mason, P.A., Andrews, K.M., Bjorkland, R., Cai, Y. \& Bell, R. (2006) Eighteen years of saturation tagging data reveal a significant increase in nesting hawksbill sea turtles (Eretmochelys imbricata) on Long Island, Antigua. Animal Conservation, 9, 302-307.

Richardson, P.B., Bruford, M., Calosso, M.C., Campbell, L.M., Clerveau, W., Formia, A. et al. (2009) Marine turtles in the Turks and Caicos Islands: remnant rookeries, regionally significant foraging stocks and a major turtle fishery. Chelonian Conservation and Biology, 8, 192-207.

Ross, J.P. \& Ottenwalder, J.A. (1983) The leatherback sea turtle, Dermochelys coriacea, nesting in the Dominican Republic. In Advances in Herpetology and Evolutionary Biology (eds A.G.J. Rhodin \& K. Miyata), pp. 706-712. Museum of Comparative Zoology, Harvard University, Cambridge, USA.

Santidrian Tomillo, P., Saba, V.S., Piedra, R., Paladino, F.V. \& Spotila, J.R. (2008) Effects of illegal harvest of eggs on the population decline of leatherback turtles in Las Baulas Marine National Park, Costa Rica. Conservation Biology, 22, 1216-1224.

Schroeder, B. \& Murphy, S. (1999) Population surveys (ground and aerial) on nesting beaches. In Research and Management Techniques for the Conservation of Sea Turtles (eds K.L. Eckert, K.A. Bjorndal, F.A. Abreu-Grobois \& M. Donelly), pp. 45-53. IUCN/Species Survival Commission Marine Turtle Specialist Group Publication No. 4, Blanchard, USA. 
Stam, S. \& S Tam, R. (1992) Turtle trouble in the Dominican Republic. Marine Turtle Newsletter, 57, 19-21.

Stewart, K., Johnson, C. \& Godfrey, M.H. (2007) The minimum size of leatherbacks at reproductive maturity, with a review of sizes for nesting females from the Indian, Atlantic and Pacific Ocean Basins. Herpentological Journal, 17, 123-128.

Troëng, S., Chacón, D. \& Dick, B. (2004) Possible decline in leatherback turtle Dermochelys coriacea nesting along the coast of Caribbean Central America. Oryx, 38, 395-403.

Troëng, S., Harrison, E., Evans, D., De Haro, A. \& Vargas, E. (2007) Leatherback turtle nesting trends and threats at Tortuguero, Costa Rica. Chelonian Conservation and Biology, $6,117-122$.

Troëng, S. \& Rankin, E. (2005) Long-term conservation efforts contribute to positive green turtle Chelonia mydas nesting trend at Tortuguero, Costa Rica. Biological Conservation, 121, 111-116.

Wielgus, J., Cooper, E., Torres, R. \& Burke, L. (2010) Coastal Capital: Dominican Republic. Case Studies on the Economic Value of
Coastal Ecosystems in the Dominican Republic. Working paper. World Resources Institute, Washington, DC, USA.

\section{Biographical sketches}

Ohiana Revuelta has interests in wildlife conservation. Her research is focused on marine turtles of the Dominican Republic. Yolanda M. LEÓN is Secretary of the environmental NGO Grupo Jaragua. Her research focuses on the threatened species of the Dominican Republic, including work with marine turtles, cetaceans and avifauna. PABLo FeLIz is a student member of Grupo Jaragua. BREndAn J. Godley coordinates the Marine Turtle Research Group at the University of Exeter, UK, and is involved in projects on the conservation of marine turtles and mammals in several countries. JUAN A. RAGA has participated in research projects on marine vertebrate conservation and parasitology at the University of Valencia. Jesús Tomás has participated in a number of research projects and contracts for the conservation of marine turtles in the Mediterranean, Africa and the Caribbean. 